\section{Global Journal of Arts Education}

Volume 07, Issue 1, (2017) 19-25

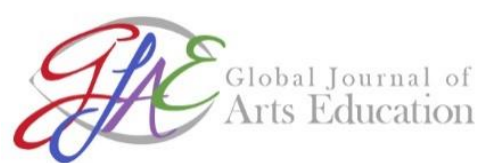

www.gjae.eu

\title{
Visual rhetoric in educational animations: An analysis on TED Education Lessons
}

Merve Ersan Senoymak*, Department of Graphic Design, Faculty of Art and Design, Gazi University, 06560 Yenimahalle/Ankara, Turkey.

\section{Suggested Citation:}

Senoymak, M.E. (2017). Visual rhetoric in educational animations: An analysis on TED Education Lessons. Global Journal of Arts Education. 7(1), 19-25

Received September 24, 2016; revised December 19,2016; accepted February 13, 2016.

Selection and peer review under responsibility of Prof. Dr. Ayse Cakir Ilhan, Ankara University, Turkey.

(C)2017 SciencePark Research, Organization \& Counseling. All rights reserved.

\begin{abstract}
Today, developments in the field of computer technology have facilitated the application of animations in computer environment and also led to the widespread use of animation in the scope of computer-aided education. Educational animations engage the learners of all ages and make the learning experience enjoyable in many areas such as physics, chemistry, biology and social sciences. Thanks to the possibilities of animation, many concepts that might be difficult to learn with static images can be described very attractively and in a catchy way. At this point, rhetorical figures can be applied to animations in order to increase the effectiveness of the messages. TED Education Lessons can be given as a successful example of educational animations in this field. TED (Technology, Entertainment, Design) Education is a series of lessons run by a private non-profit foundation, under "Lessons worth Sharing" slogan. These lessons are 3-10 minutes of educational and enjoyable animations, which are created with the collaboration of professional educators and animators. There are various animations on TED Education webpage that aim learners starting from the age of primary school and higher. Through TED Education lessons, this research examines how education takes the advantage of animation and how animations benefit from the rhetorical figures.
\end{abstract}

Keywords: Animation, visual rhetoric, rhetorical figures, educational animations, TED Education.

*ADDRESS FOR CORRESPONDENCE: Merve Ersan Senoymak, Department of Graphic Design, Faculty of Art and Design, Gazi University, 06560 Yenimahalle/Ankara, Turkey. E-mail address: mervesenoymak@gmail.com 


\section{Educational Animations and TED Education Lessons}

Today, we face a new technological change every day and it is unlikely to make the education system independent of these changes. Education aims to provide the knowledge and show learners how to use and benefit from this knowledge. In this context, it is useful to take the advantage of technology and multimedia environments. In the new millennium, pictorial forms of teaching are likely to continue to grow as a complement to verbal forms of teaching (Pailliotet \& Mosenthal, 2000). Besides, the variety of developments related to the educational technology leads to a proliferation of activities suitable to the contemporary understanding of education.

Animation refers to a simulated motion picture depicting movement of drawn (or simulated) objects (Mayer \& Moreno, 2002). Movement has always attracted and entertained people, but animation is not just a simple process of entertainment. Depending on where and how it is used and its quality, animation can handle messages and make the subject interesting. Animation has a great potential to improve human learning-especially when the goal is to promote deep understanding (Mayer \& Moreno, 2002). Many concepts that might be difficult to learn with static images can be described very attractively thanks to the possibilities of animation. It facilitates the understanding of the concepts that might be difficult to stimulate in the mind and makes the learning process enjoyable. In short, animation can be a powerful technique when used appropriately.

Animation helps to understand the complex information, through a good analysis and clarification of the subject, within symbols and illustrations. According to Wright, Milroy \& Lickorish (1999) compared with static diagrams, animation increases readers' willingness to study a range of graphic genres (maps, time-lines, drawings of unfamiliar objects). Combined with color and motion features, animations increase the memorability of the subject and it can provide an effective learning by appealing to the eye and the ear at the same time. Learning retention rate studies show that people remember approximately $10 \%$ of what is read, $20 \%$ of what is heard, $30 \%$ of what is seen, and $50 \%$ of what is both seen and heard (Najjar, 1996). For example, while retention rate is $20 \%$ when reading a book; it increases to $40 \%$ in texts supported by sound, images and interactive multimedia (Usun, 2006).

In the field of educational animations, TED Education is a notable platform, because it holds successful examples. TED (Technology, Entertainment, Design), a global nonprofit organization whose mission is "Ideas worth Spreading" announced its education platform, TED-Ed in 2011. TED-Ed is broadcasted in its own website and Youtube channel. TED-Ed videos are shorter (3-10 minutes) than the normal 18-minute TED Talks and they are based on animations, which try to make learning exciting and to catalyze curiosity in learners. The lessons are created with the collaboration of professional educators and animators worldwide.

The subjects of TED Ed animations are; the Arts, Business and Economics, Design, Engineering and Technology, Health, Literature and Language, Mathematics, Philosophy and Religion, Psychology, Science and Technology, Social Studies, Teaching and Education, Thinking and Learning. They are also divided into categories by their content, target student and duration. The animations are accompanied by narration and often subtitles. The narration is in conversational style rather than formal according to the research conducted by Mayer \& Moreno with college students (2002).

1. Students learn more deeply from animation and narration than from narration alone.

2. Students learn more deeply when corresponding portions of the narration and animation are presented at the same time than when they are separated in time.

3. Students learn more deeply from animation and narration when extraneous words, sounds (including music), and video are excluded rather than included.

4. Students learn more deeply from animation and narration when the narration is conversational rather than formal style (i.e., involving "I" and "you"). 


\section{Visual Rhetoric}

Rhetoric is the art of persuasive communication in verbal language, which was first used by ancient Greek. 2500 years ago the Greeks were already concerned with proficiency in communication (Ehses \& Lupton, 1988). According to Aristotle, rhetoric is concerned with discovering all the available means of persuasion in any given situation, either to instruct an audience (rational appeal), to please an audience and win it over (ethical appeal), or to move it (emotional appeal) (Ehses, 1984).

Ehses states, "The essence of a rhetorical figure is an artful departure from the ordinary way of speaking. Even though rhetoric is concerned with verbal language, rhetorical figures can be applied to visual language as well. Rhetoric, the art of saying something in a new form, suggests ways to construct appropriate messages" (Ehses, 1984). In many areas of graphic design such as advertising (which is of one of the most persuasive communication forms), poster design, visual identity etc., visual rhetoric is often used in order to attract the attention of the viewer and engage him/her.

In the same manner, in educational animations the purpose is creating effective visual communication that is satisfying in functional and aesthetical aspects. In this practice, the designer of the animation is a kind of sender who should transfer information in a clear and understandable way to the audience by using visual language. $\mathrm{S} /$ he deals with concepts and uses visual elements in order to convert a theoretical concept into a message in visual unity. Moreover, the animation should attract the attention at the first place in order to engage the viewer with its concept and to give the message. Therefore, according to Lengler \& Moere (2009), the truth needs not only be adequately represented, it also needs to be effective. In this case, visual rhetoric is used to make the truth more effective.

In order to increase the persuasiveness of the message in any means of communication, the art of rhetoric benefits from rhetorical figures such as metaphors, puns, similes, ironies and analogies etc. Metaphors are one of the best-known rhetorical figures. Rhetorical figures are divided into two groups; schemes and tropes (Ehses, 1984). Tropes alter the customary reference of signs and schemes alter their normal arrangement. When using tropes, there is an intention for the words to have a meaning that is different than the literal meaning. According to Ehses, a figure of speech is a departure from the ordinary use of language. A trope is the use of figurative language - via word, phrase, or even an image - for artistic effect such as using a figure of speech (Examples of Trope, 2014). Most common tropes and their meanings are described as follows:

- As one of the best-known rhetorical figures, metaphors compare two things that have very little in common but do share a trait or characteristic (Examples of Trope, 2014). Metaphor is an implied comparison between two unlike objects that have some structural similarity.

- Personification is a kind of metaphor, which attributes human qualities to things that are not human.

- Metonymy represents one term with another, which is related to it by temporal, spatial or casual proximity, rather than by resemblance, as in the expression "a hand of cards" or "ring finger" (Ehses \& Lupton, 1988).

- Synecdoche uses a part of something to represent the whole.

- Simile compares two things that share some attributes in common, such as "bright like a sun".

- Antithesis contrasts two distinct ideas or objects, as in "A small step for a man, one giant leap for the mankind"

- Irony uses a word or sign to mean its opposite from the literal meaning as in "clear as mud".

- Hyperbole is exaggeration.

- Amplification expands in detail the parts of an object or argument.

- Pun plays on two words or images that are similar in sound or shape, but different in meaning. 
- Oxymoron uses words that contradict each other such as "painfully beautiful", "tiny elephant" etc.

- Periphrasis uses a well-known saying rather than saying directly.

\section{Tropes in TED Education Animations}

Teng \& Sun (2002) state that, pictorial tropes' designs are often clever, creative, sometimes surprising and explorative, yet they are easy to consume and designedly so. In this research, visual rhetoric in TED Education lessons is analyzed by examining the tropes in one animation in each educational level (elementary, high school, college) of this learning platform.

"How do vitamins work?" is a lesson aimed at elementary school students. By using tropes, this animation explains what the vitamins are, how they get into our bodies and why they are so crucial. At the beginning of the animation, the vitamins are illustrated and each of them is described in detail, which is an example of amplification (Figure 1a). Vitamins are personified as builders, defenders and maintenance workers of the human body. In Figure $1 \mathrm{~b}$, representing vitamin-d as a maintenance worker is both personification and metaphor. Since vitamin-d is responsible from muscle building, it is shown as a maintenance worker; two unlike ideas share some structural similarity. When used correctly, metaphor connects one subject with another that is not obviously related in a way that is both stylistically pleasing and concise (McGuigan, 2011). Also, inflating the muscles with pump makes an example of hyperbole. In Figure 1c, besides the use of personification, representing healing with first aid band creates a synecdoche.

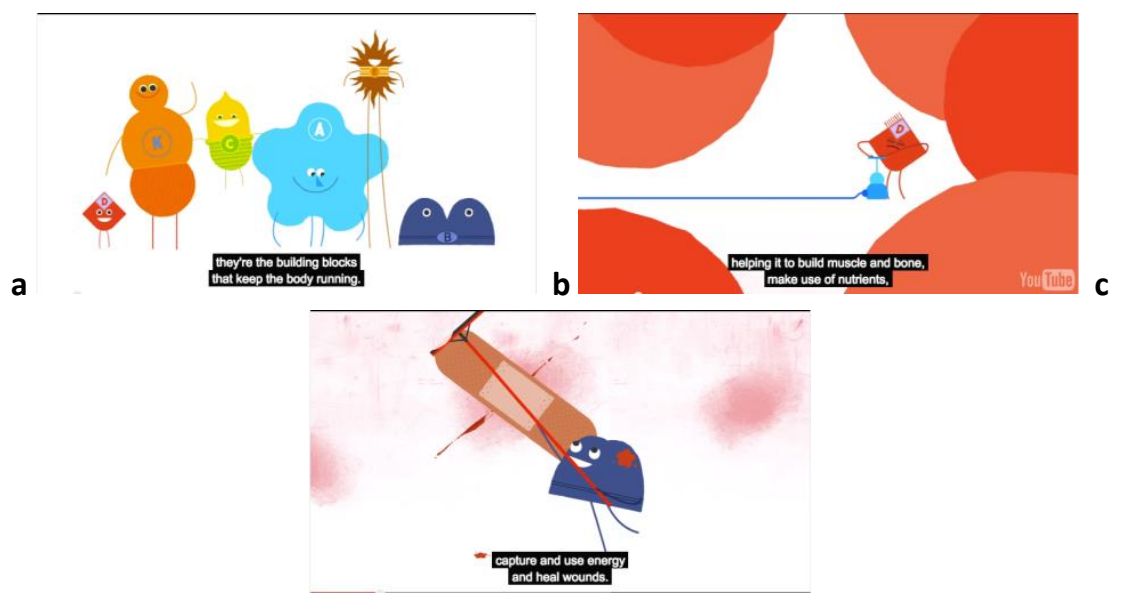

Figure 1. Screenshots from "How do vitamins work?"

"Cell vs. virus: A battle for health" is a lesson aims at both middle school and high school students. The animation makes a story of a virus getting into human body. Then, it takes the audience to a journey into the cell, introducing the microscopic weapons and warriors that play a role in the battle for human health. In the story, organelles of the cell are illustrated metaphorically, such as factories, castles and powerhouses. For example, since mitochondria are responsible from producing energy to the cell, it is a powerhouse. In Figure 2a, cell membrane is illustrated as a castle that protects the cell. A figure of similarity (e.g. visual metaphor) suggests that two images are the same in some way and invites the viewer to draw an analogy between the two images to understand how they relate to one another (Lengler \& Moere, 2009). Here, the protective features of a castle are used as a metaphor Figure $2 \mathrm{~b}$. Likewise, enzymes that responsible from protecting the cell are represented as soldiers, which create a personification and a metaphor at the same time (Figures $2 b$ and $2 c$ ). Figure $2 b$, also conforms to the pattern of synecdoche, because the part stands for the whole. Here, all of the illustrations in Figure $2 \mathrm{~b}$ represent the whole organelles of the cell in the human body. 


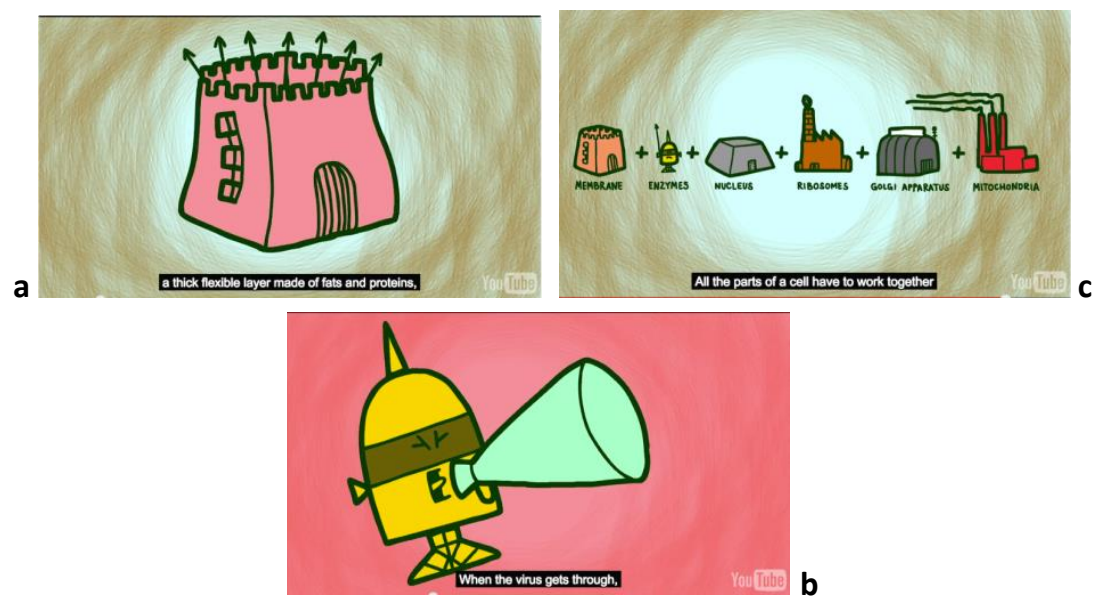

Figure 2. Screenshots from "Cell vs. virus: A battle for health"

In Figure 3a, a virus trying to attack to the cell is entering the cell in a Trojan horse. Trojan horse is a wooden horse model, in which Odysseus built to overcome the walls of Troy and the sneak into the city during Trojan War. In terms of rhetoric, this is an example of periphrasis because a character of a common tale is used in the story. Certainly, in order to understand this message, the audience of the lesson should know about Trojan horse.
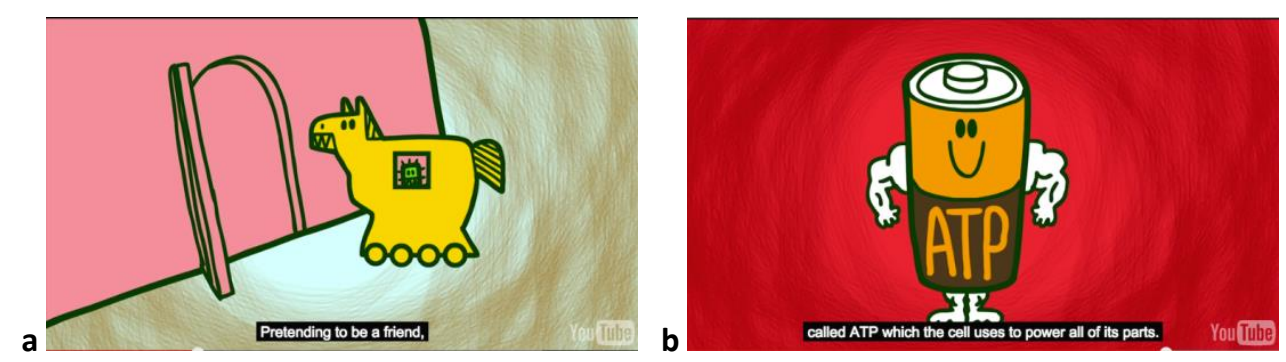

Figure 3. Screenshots from "Cell vs. virus: A battle for health"

In Figure 3b, the lesson introduces the high-energy molecule called ATP, for which the cell uses to power all of its parts. At this point, a character is created with many rhetorical figures. It has human attributes such as face, arms, legs, muscles and a body like a fuel tin. While human attributes create personification, fuel tin and strong arms creates a metaphor at the same time, because ATP is used for power all the parts of the cell. Again, the character conforms to that of synecdoche, since it stands for the whole ATP molecules in the cell.

"How playing an instrument benefits your brain?" is a lesson created for students in college and university levels. In this lesson, playing an instrument is associated with an activity like a full-body brain workout. The animation examines some of the long-term positive effects of this mental workout.
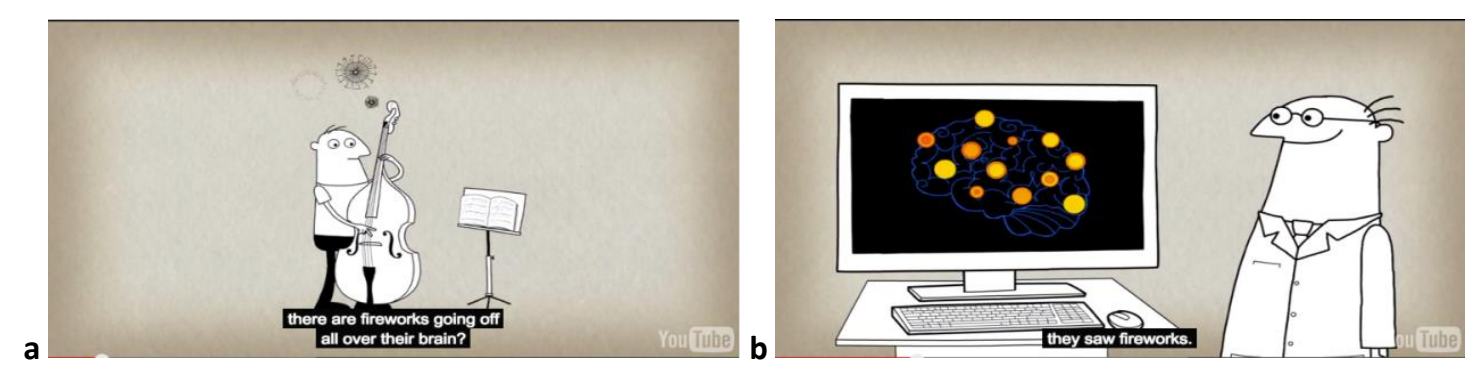

Figure 4. Screenshots from "How playing an instrument benefits your brain?" 
A trope such as a metaphor or a pun rests on a deviant usage that is irregular, or breaks a rule (McQuarrie \& Mick, 2003). In Figure $4 a$ and 4b, brain functions are metaphorically associated to fireworks. Moreover, in Figure 5a, the brain creates a metaphor because its functions are associated with a kind of exercise like a body workout. The brain illustration also makes a visual pun, since it stands for the brain and a muscle of the arm concurrently.

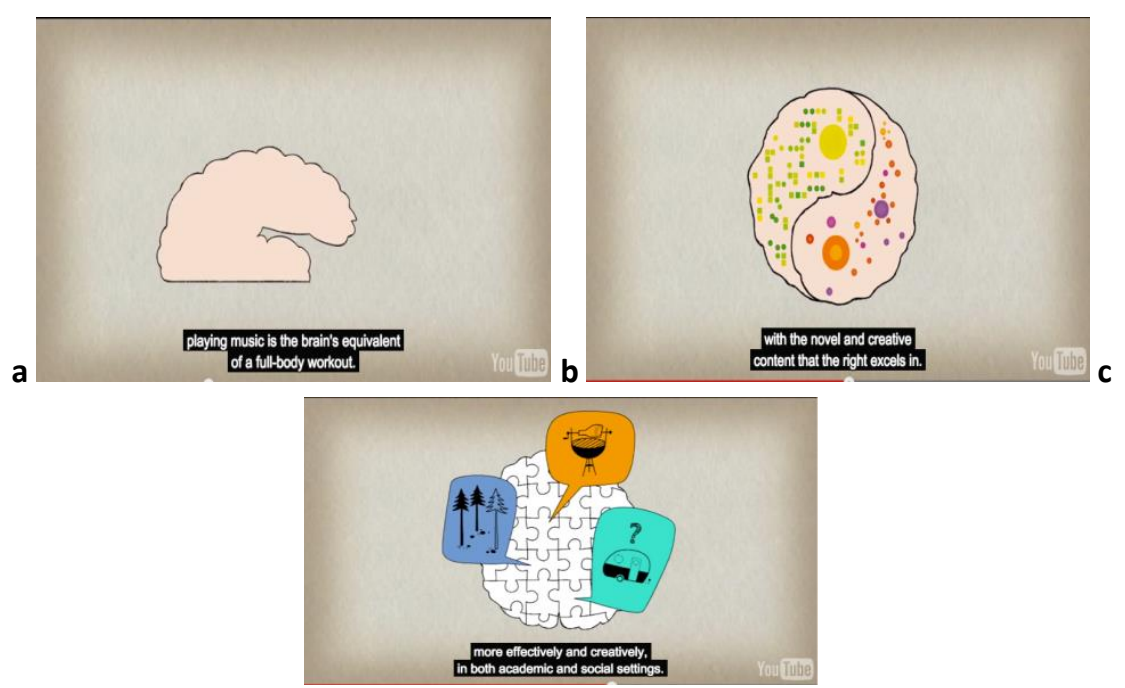

Figure 5. Screenshots from "How playing an instrument benefits your brain?"

A metaphor connects one subject with another that may not be obviously related (McGuigan, 2011). In Figure 5b, another metaphor appears when left and right side of the brain turn into a yin and yang symbol expressing the balance and harmony between these sides. The brain still keeps its form, which makes it a visual pun. Figure $5 c$ provides another visual pun, this time brain is a puzzle. Using the puzzle has a metaphorical approach as well, because brain's problem solving functions are likening to a puzzle. Finally, the symbols of barbecue, trees and camper build a synecdoche because symbols stand for the whole same kind of activities in social settings.

\section{Conclusions}

One of the most important points of using rhetorical figures is creating effectiveness in communication. Rhetorical figures are often used in advertising in order to persuade the consumer, create a behavioral change and finally sell. However the aim of using a visual rhetorical figure is not always try to persuade. Rhetoric is a tool that enhances composition; its aim is to persuade, to inform, to express a personal thought, or simply to entertain the reader (McGuigan, 2011). As in all communication processes, educational animations require successful communication in order to give the message and provide learning. In educational animations, rhetorical figures are used to inform the learner in a more interesting and enjoyable way. This time, the aim is not a behavioral change or making profit, but support learning.

In educational animations, rhetorical figures can engage the viewer, enhance the meaning creation process and make the learning more efficient. Tropes such as metaphor, personification, pun etc. can also make some parts of the story enjoyable, more impressive and catchy for the viewer. In this way, learning can be more permanent. However, since rhetoric is far from direct expression, visual rhetorical figures require more cognitive effort in meaning creation (Lengler \& Moere, 2009). They demand significant effort both from the designer to constitute them and from the viewer to decode them. Therefore, all visual arrangements should be considered in terms of visual communication and rhetorical figures should be used strategically.

In TED Education lessons examined in this research, rhetorical figures are shaped primary in verbal language. In other words, verbal rhetoric is constituted before visual rhetoric. Metaphors are one of the most widely used rhetorical figures in these animations. Moreover, the examples analyzed in this research demonstrate that rhetorical figures can be used in every level of educational animation 
beginning from elementary school to college. The important point is using common tropes for the academic level of the audience.

\section{References}

Ehses, H. H. (1984). Representing Macbeth: A case study in visual rhetoric. Design Issues, 53-63.

Ehses, H., \& Lupton, E. (1988). Rhetorical handbook: An illustrated manual for graphic designers. Design Papers, 5, 1-39.

Examples of Trope (2014). Retrieved June 7th, 2015, from: http://examples.yourdictionary.com/examples-oftrope.html

Lengler, R., \& Moere, A. V. (2009). Guiding the viewer's imagination: How visual rhetorical figures create meaning in animated infographics. 13th International Conference Information Visualisation.

Mayer, R. E., \& Moreno, R. (2002). Animation as an aid to multimedia learning. Educational psychology review, 14(1), 87-99.

McGuigan, B. (2011). Rhetorical devices: A handbook and activities for student writers. Prestwick House Inc.

McQuarrie, E. F., \& Mick, D. G. (2003). Visual and verbal rhetorical figures under directed processing versus incidental exposure to advertising. Journal of consumer research, 29(4), 579-587.

Najjar, J. L. (1996). Multimedia information and learning. Journal of Educational Multimedia and Hypermedia, $5(2), 129-150$.

Pailliotet, A. W., \& Mosenthal, P. B. (eds.). (2000). Reconceptualizing literacy in the age of media, multimedia, and hypermedia, JAI/Ablex, Norwood, NJ.

Teng, N. Y., \& Sun, S. (2002). Grouping, simile, and oxymoron in pictures: A design-based cognitive approach. Metaphor and Symbol, 17(4), 295-316.

Usun, S. (2006). Uzaktan egitim. Ankara: Nobel Yayin Dagitim.

Wright, P., Milroy, R., \& Lickorish, A. (1999). Static and animated graphics in learning from interactive texts. European Journal of Psychology of Education, 14(2), 203-224. 